\title{
Proximate causes of deforestation in the Bolivian lowlands: an analysis of spatial dynamics
}

\author{
Robert Müller • Daniel Müller • Florian Schierhorn • \\ Gerhard Gerold • Pablo Pacheco
}

Received: 21 April 2011/Accepted: 7 October 2011/Published online: 28 October 2011

(C) The Author(s) 2011. This article is published with open access at Springerlink.com

\begin{abstract}
Forests in lowland Bolivia suffer from severe deforestation caused by different types of agents and land use activities. We identify three major proximate causes of deforestation. The largest share of deforestation is attributable to the expansion of mechanized agriculture, followed by cattle ranching and small-scale agriculture. We utilize a spatially explicit multinomial logit model to analyze the determinants of each of these proximate causes of deforestation between 1992 and 2004. We substantiate the quantitative insights with a qualitative analysis of historical processes that have shaped land use patterns in the Bolivian lowlands to date. Our results suggest that the expansion of mechanized agriculture occurs mainly in response to good access to export markets, fertile soil, and intermediate rainfall conditions. Increases in small-scale agriculture are
\end{abstract}

Electronic supplementary material The online version of this article (doi:10.1007/s10113-011-0259-0) contains supplementary material, which is available to authorized users.

R. Müller $(\bowtie) \cdot$ G. Gerold

Department of Landscape Ecology, Institute of Geography,

Georg-August-Universität Göttingen, Goldschmidtstr. 5,

37077 Göttingen, Germany

e-mail: robemule@yahoo.com

D. Müller

Geography Department,

Geomatics Lab, Humboldt-Universität zu Berlin,

Unter den Linden 6, 10099 Berlin, Germany

D. Müller · F. Schierhorn

Leibniz Institute of Agricultural Development in Central and Eastern Europe (IAMO), Theodor-Lieser-Str. 2,

06120 Halle (Saale), Germany

P. Pacheco

Center for International Forestry Research (CIFOR),

Jalan CIFOR Situ Gede, Bogor Barat 16115, Indonesia mainly associated with a humid climate, fertile soil, and proximity to local markets. Forest conversion into pastures for cattle ranching occurs mostly irrespective of environmental determinants and can mainly be explained by access to local markets. Land use restrictions, such as protected areas, seem to prevent the expansion of mechanized agriculture but have little impact on the expansion of smallscale agriculture and cattle ranching. The analysis of future deforestation trends reveals possible hotspots of future expansion for each proximate cause and specifically highlights the possible opening of new frontiers for deforestation due to mechanized agriculture. Whereas the quantitative analysis effectively elucidates the spatial patterns of recent agricultural expansion, the interpretation of long-term historic drivers reveals that the timing and quantity of forest conversion are often triggered by political interventions and historical legacies.

Keywords Bolivia - Amazon - Deforestation - Proximate causes $\cdot$ Spatial analysis $\cdot$ Multinomial logistic regression

\section{Introduction}

Reducing tropical deforestation is of global importance for the mitigation of climate change and for the conservation of biodiversity (IPCC 2007). Bolivia is among the ten countries with the highest absolute forest loss over the last decade (FAO 2010). However, the country still harbors critical regions of intact and highly diverse tropical lowland rainforests totaling approximately $400,000 \mathrm{~km}^{2}$ (based on Killeen et al. 2007). Deforestation is the result of different land use activities by various classes of agents (Killeen et al. 2008). For a better understanding of the patterns and processes of deforestation, we have analyzed 
the factors that determine the expansion of three forestdepleting land use types that are the main proximate causes of deforestation in Bolivia: mechanized agriculture, smallscale agriculture, and cattle ranching. These categories can explain a very large portion of the deforestation occurring in the Bolivian lowlands and can differentiate between the key groups of land use agents. Similar categories have also been adopted in other studies in the Brazilian Amazon (e.g., Kirby et al. 2006). Herein, we conduct a multinomial spatial regression analysis of forest conversion in the Bolivian lowlands between 1992 and 2004 using the three proximate causes and stable forest as response categories. The model outcome allows us to quantify the effects of the hypothesized determinants of forest conversion by interpreting the significance, sign, and strength of the logit coefficients (Chomitz and Gray 1996; Müller and Zeller 2002; Munroe et al. 2004). Moreover, the regression results help in the development of spatial scenarios of future deforestation (e.g., Verburg et al. 2006).

Improved knowledge of future land use trends can be valuable for informed policy decision-making and management interventions, such as those under the REDD mechanism (reducing emission from deforestation and degradation, Miles and Kapos 2008). Regression analysis, however, provides information about only the statistical associations between independent and dependent variables and does not explain the underlying causal interactions among the different variables included in the analysis. To broaden our understanding of contemporary land use changes and the regression results, we also assessed the historical land use processes taking place in five different zones identified in lowland Bolivia, such as government programs previously aimed to develop agriculture in specific parts of the lowlands.

The overall objective of this study is to achieve a better understanding of the processes and conditions explaining land use/cover change in lowland Bolivia based on a quantitative regression analysis of recent changes in land use and a qualitative understanding of historical changes in land use trends. We use these insights to predict impending deforestation patterns that in turn augment the knowledge base that can be used to develop strategies and policy instruments to reduce pressure on forested lands.

\section{Methods and data}

Study area and historical land use

The study area includes all forests in the Bolivian lowlands. The Bolivian lowlands are defined as all land in Bolivia below $500 \mathrm{~m}$ above sea level covering $670,000 \mathrm{~km}^{2}$ between the Andes in the West and neighboring countries in all other directions. This area currently includes approximately $400,000 \mathrm{~km}^{2}$ of forests, corresponding to about $90 \%$ of the original lowland forest cover. The annual deforestation rate was approximately $0.5 \%$ between 1992 and 2004 (Killeen et al. 2007), which is comparable to the deforestation rate in the Brazilian Amazon in that period (FAO 2010). Areas where no natural forest occurs or where forests were cleared prior to 1992 were excluded from the analysis (i.e., the Beni savannahs in the north, the wetlands of the Pantanal in the southeast and the Cerrado formations of the Chiquitania in the east).

For a qualitative analysis of the historical processes that shape land use patterns in the Bolivian lowlands to date, we roughly divide the Bolivian lowland forests into five zones (Fig. 1); similar, but more detailed divisions have been proposed by Ibisch et al. (2003), Montes de Oca (2004), Killeen et al. (2008), Navarro and Maldonado (2002) and Pacheco (1998).

The northern part of the study area (referred to as the "Amazonian North") is covered by Amazonian moist rainforests and has a very low population density. Land estates for rubber extraction were established 100-150 years ago during the rubber boom (Gamarra Téllez 2004), which attracted a population that originated largely from other zones of the Bolivian lowlands. Recently, there has been a growing proportion of internal migrants from the highlands (Stoian and Henkemans 2000). After the final collapse of the rubber economy in the mid-1980s, the major current uses of the forest are Brazil nut extraction and selective logging (Stoian and Henkemans 2000). Deforestation is predominantly caused by cattle ranching on formerly forested pastures (Pacheco et al. 2009).

The northwest region of the study area (termed "northern Andean piedmont") comprises very humid Amazonian rainforest. Most people living in this area are national settlers who have arrived within the past 30 years from western Bolivia and cultivate rice and perennial crops, e.g., banana, with few external production inputs. Migration was largely planned and supported by the government in the 1960s and 1970s (Eastwood and Pollard 1985; Thiele 1995). Thereafter, most migration occurred spontaneously and was mainly driven by poverty, e.g., after the collapse of tin mining in 1985 (Pacheco 2006a). In the Chapare zone (east of Cochabamba, around Ivirgarzama, Fig. 1), coca is also an important crop. Several large indigenous territories (Tierras Comunitarias de Origen, TCO) are located in this region and belong to different lowland indigenous peoples.

The area around the city of Santa Cruz de la Sierra ("surroundings of Santa Cruz") is heterogeneous in terms of vegetation, land use, and population. It is located in the transitional zone between the Amazonian rainforests in the 
Fig. 1 The Bolivian lowlands. Source: Adapted from Killeen et al. (2007) and USGS (2004)

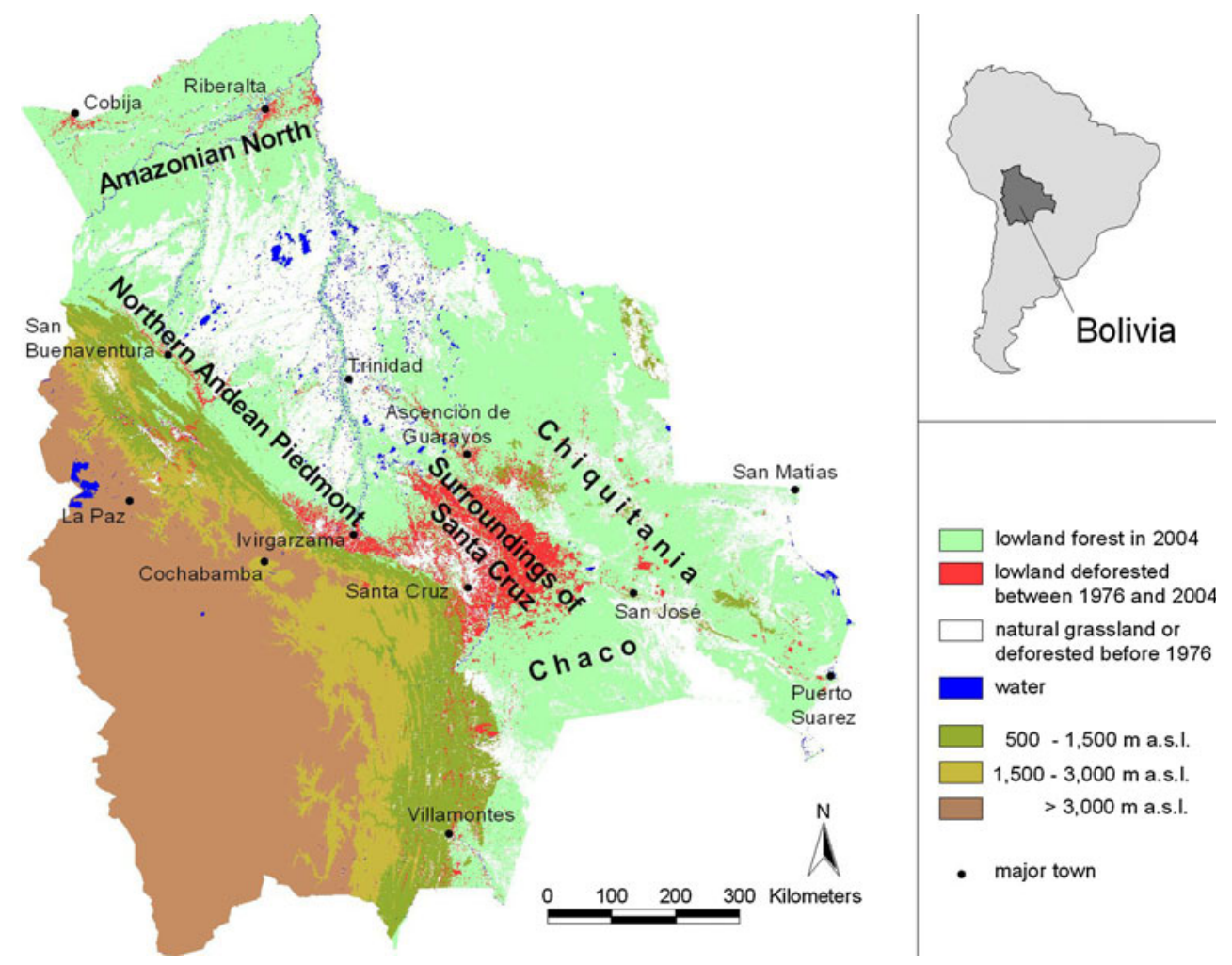

north, the Chiquitano semi-deciduous forests in the east, and the Chaco dry forest in the south (Navarro and Maldonado 2002). The alluvial soils east of the Río Grande are very fertile (Gerold 2004). Traditionally, sugarcane was the main crop and was planted near the city of Santa Cruz (Pacheco 2006a). Since the 1980s, industrial soybean production has become the most important land use (Hecht 2005); its development has been facilitated by preferential tariffs in the Andean markets, export incentives in the context of structural adjustment (Pacheco 2006a), and a development program funded by multilateral donors (Baudoin et al. 1995; Gerold 2007). Additional land uses include cattle ranching and manual agriculture (Pacheco 1998). Most of the lowland population is concentrated in this area, particularly in and around the city of Santa Cruz, which is the largest and fastest-growing town in Bolivia. It has a heterogeneous population composed of people originating from the lowlands and western Bolivia as well as immigrants from other countries (Sandoval et al. 2003).

The eastern region of the study area is called "Chiquitania" and is characterized by semi-deciduous forests growing in the poor soils of the Precambrian shield. Today's settlements were predominantly founded by Jesuits some 300 years ago (Tonelli Justiniano 2004). The most common traditional and current use of land is cattle ranching, both in natural grasslands and in pastures established on former forest land (Killeen et al. 2008). In addition, the timber industry is an important economic sector. The population mainly consists in descendants of lowland indigenous peoples.

The southern region of the study area ("Chaco") is virtually uninhabited, with the exception of the Andean foothills in the west. The predominating vegetation is Chaco dry forest. A large portion of this zone lies within the "Kaa-Iya del Gran Chaco" National Park. Only in the western parts is there enough rainfall to allow cattle ranching and limited agriculture (Killeen et al. 2008). A large proportion of the population consists of the descendents of lowland indigenous people.

Three proximate causes of deforestation

We define three major proximate causes of deforestation, following the concept of Geist and Lambin (2002). We base our definition of the proximate causes on the prevalent land use practices in the study area, which are closely related to specific social groups.

Mechanized agriculture refers to the intensive production of annual cash crops, mainly soybean, sugarcane, and rice. Soybean is often double-cropped and alternated with sunflower or wheat cultivation in the dry season (CAO 2008). Mechanized agriculture is typically based on large production units, heavy machinery, and large capital investments. Typical agents are large-scale corporations 
from Bolivia or Brazil, medium-scale national landholders, and producers of foreign origin, mainly Mennonite or Japanese. To some extent, mechanized agriculture is also practiced by national settlers, especially around San Julian (south of Ascención de Guarayos), though this group is mostly associated with small-scale agriculture. Most production involves oil and cake processing in the country and is exported mainly to the Andean market. Mechanized agriculture is concentrated to the east and north of the city of Santa Cruz. In the 1990s, mechanized agriculture expanded mainly into the floodplain east of the Río Grande; however, the recent expansion is concentrated in the area north of Santa Cruz (Killeen et al. 2007; Müller et al. 2011).

Small-scale agriculture comprises several forms of labor-intensive production of mainly rice, maize, and perennial crops, such as banana. The corresponding agents often have the combined objectives of production for subsistence and of generating cash income. Only a very small share of the products of small-scale farming is exported. Also some cattle breeding integrated in multiple purpose small-scale farming is included in this category. Typically, about two hectares per family are cultivated annually in a shifting cultivation system. The small-scale producers are mostly national settlers that have migrated from the highlands (see Killeen et al. 2008). They are mostly found in the humid areas of the northern Andean piedmont and to the north of the city of Santa Cruz. In the latter region, these producers have increasingly adopted mechanized production systems; where this has occurred, the corresponding systems are included in the category "mechanized agriculture". The population of lowland indigenous people is small and makes a minor contribution to agricultural production and deforestation (Pacheco 2006b).

Cattle ranching leads to the replacement of forests by pasture that is predominantly used for breeding and fattening cattle for beef production in Bolivia (CAO 2008). In this article, only the expansion of cattle ranching at the expense of forested areas is considered, and cattle ranching on natural grasslands was excluded from the analysis. Both systems are estimated to sustain comparable numbers of cattle (CAO 2008). Nearly, all produced beef is sold on the national market. In 2008, merely a single company exported beef (CADEX 2008) because Bolivia is not officially free from foot and mouth disease. The size of production units ranges from a few hectares to several thousand hectares. However, a census of cattle conducted by the National Veterinary Service (Servicio Nacional de Sanidad Agropecuaria e Inocuidad Alimenticia, SENASAG) has shown that in the lowlands, over $50 \%$ of cattle belong to farms with 1,000 animals or more. On average, the levels of production technology and efficiency are low
(Merry et al. 2002). Cattle ranching is widespread in the Bolivian lowlands, but its importance for deforestation is especially high in the Chiquitania and in the Amazonian north. Most cattle ranchers are Bolivians, but Brazilian capital plays an important role, especially in areas near the border with Brazil (see Killeen et al. 2008).

\section{Mapping the proximate causes of deforestation}

In order to map the expansion of the proximate causes of deforestation, we used a stepwise procedure to assign the three proximate causes of land use change to the areas that were deforested between 1992 and 2004 (Fig. 2). This period is assumed to be long enough to exhibit reliable trends; moreover, suitable data are available. Deforested areas as well as areas of stable forest were identified based on the report by Killeen et al. (2007) that distinguished forest and non-forest in the lowlands over five different points in time, including 1992 and 2004. We excluded the classes "Cerrado" and "deforestation in Cerrado" defined by Killeen et al. (2007) because these vegetation types have no closed canopy cover, which makes estimation of deforestation difficult. They used unsupervised classifications of Landsat satellite data, corrected the results manually, and validated the maps with aerial videography. For the region in the department of Santa Cruz, we assigned all areas deforested between 1992 and 2004 to one of the three defined proximate causes of deforestation using an existing land use map (Museo Noel Kempff and Prefectura de Santa Cruz 2008), which distinguishes seven classes of forest-replacing agricultural land use in 2005. This map has similar characteristics to the map of Killeen et al. (2007) and was prepared by the same institution, the Museo Noel Kempff in Santa Cruz (full name Museo de Historia Natural Noel Kempff Mercado). It was based on a classification of 20 Landsat images and was thoroughly refined in cooperation with the most important associations of agricultural producers (Museo Noel Kempff and Prefectura de Santa Cruz 2008). We reclassified this map according to the three proximate causes of deforestation. Outside the department of Santa Cruz, several sources were used to allocate deforested areas to one of the three proximate causes. We first undertook a preliminary classification of the deforested areas according to the land use traditions described in "Study area and historical land use" and agricultural statistics from the CAO (2008). Deforested areas in the northern Andean piedmont were preliminary classified as small-scale agriculture; deforested areas in other zones (outside Santa Cruz) were assigned to cattle ranching. Agricultural statistics from the CAO (2008) suggest that virtually no mechanized agriculture exists or existed outside the department of Santa Cruz and that crop production is very low in the Amazonian north. This incipient classification was refined using unpublished spatial data obtained from the 
Fig. 2 Procedure to map the proximate causes of deforestation. Source: Authors

\begin{tabular}{|c|c|}
\hline Step & Information source \\
\hline $\begin{array}{l}\text { Delineation of areas deforested between } 1992 \text { and } \\
2004\end{array}$ & Remote sensing by Killeen et al. (2007) \\
\hline \multicolumn{2}{|c|}{$\downarrow$} \\
\hline $\begin{array}{l}\text { Assignment of deforested areas within the } \\
\text { department of Santa Cruz to the three proximate } \\
\text { causes of deforestation }\end{array}$ & $\begin{array}{l}\text { Map of land use in } 2005 \text { in Santa Cruz (Museo Noel } \\
\text { Kempff and Prefectura de Santa Cruz 2008) }\end{array}$ \\
\hline \multicolumn{2}{|c|}{$\downarrow$} \\
\hline $\begin{array}{l}\text { Preliminary assignment of deforested areas in the } \\
\text { remaining study area to the three proximate causes } \\
\text { of deforestation }\end{array}$ & $\begin{array}{l}\text { Prevailing traditional land use (as described in the } \\
\text { section on the study area) and agricultural statistics } \\
\text { from CAO (2008) }\end{array}$ \\
\hline \multicolumn{2}{|c|}{$\downarrow$} \\
\hline Refinement of results & $\begin{array}{l}\text { National Agrarian Reform Institute INRA (Pacheco } \\
2006 b \text { ); livestock survey (Animal Health Service } \\
\text { SENASAG); visual evaluation of CBERS satellite } \\
\text { imagery in Northern Amazon and Northern Andean } \\
\text { Piedmont }\end{array}$ \\
\hline \multicolumn{2}{|c|}{$\downarrow$} \\
\hline Quantitative accuracy assessment & CBERS satellite imagery \\
\hline
\end{tabular}

National Institute for Agrarian Reform (Instituto de Reforma Agraria, INRA) and derived from the sanitation process occurring in lowland Bolivia (see Pacheco 2006b), which distinguishes between landholdings dedicated to crop production or cattle ranching. Results were further improved by incorporating data from an unpublished survey of the SENASAG that indicated the cattle herd size for every landholding in Bolivia. Finally, we conducted a visual evaluation of critical areas (Northern Andean piedmont and Amazonian north) using China-Brazil Earth Resource Satellite (CBERS) satellite images (INPE 2010). The panchromatic channel of the high-resolution camera (HRC) of the CBERS has a resolution of $2.5 \mathrm{~m}$, which allows for visual distinction between pasture and agriculture by a qualitative analysis of criteria such as shape, uniformity, and reflectance of clearings. Deforestation patterns from small-scale agriculture typically consist of many small rectangular patches with different degrees of vegetation removal. In contrast, clearings for pastures are generally larger and more uniform, often with visible drinking ponds, and they often leave a few scattered trees behind (see Supplemental Material for examples).

A quantitative validation of the final map was conducted for the area within the department of Santa Cruz, where this map is based on Museo Noel Kempff and Prefectura de Santa Cruz (2008). The validation utilizes 18 CBERS HRC scenes that are spread over the entire lowland area of the department of Santa Cruz. For each proximate cause of deforestation identified on the final map, 150 pixels were randomly chosen within the area covered by the 18 satellite images. Proximate causes of deforestation were identified in the 450 selected pixels based on a visual interpretation of the satellite images, and the results were then compared with the final map. A coincidence of $88 \%$ was found (weighted average of the user's accuracy); the allocation disagreement was $6.5 \%$ and the quantity disagreement 5.5\% (see Pontius and Millones 2011, details in the Supplemental Material).

Small errors may have been caused by the minute size of some clearings for small-scale farming or by changing land use within the analyzed period (1992-2004), e.g., patches of small-scale agriculture may have been missed if they became secondary forest or were converted to cattle ranching before 2004 .

The resulting map (Fig. 3) approximates land use changes in the Bolivian lowlands by incorporating the best data and information currently available. Table 1 summarizes the share of deforestation between 1992 and 2004 due to each of the three proximate causes. The expansion of mechanized agriculture made the largest contribution (54\%), followed by cattle ranching (27\%) and small-scale agriculture (19\%). Killeen et al. (2008) found a much higher share of deforestation due to small-scale agriculture because they assigned deforestation in northeastern Bolivia to lowland indigenous communities. Based on the different sources mentioned and our knowledge of the area, we mostly attribute deforestation in this area to cattle ranchers.

\section{Multinomial logistic regression}

We have formulated a spatially explicit multinomial logistic regression model (MNL, e.g., Chomitz and Gray 1996; Hosmer and Lemeshow 2000; Menard 2002; Long and Freese 2006). Multinomial logistic regression is most suitable here because the dependent variable is categorical 


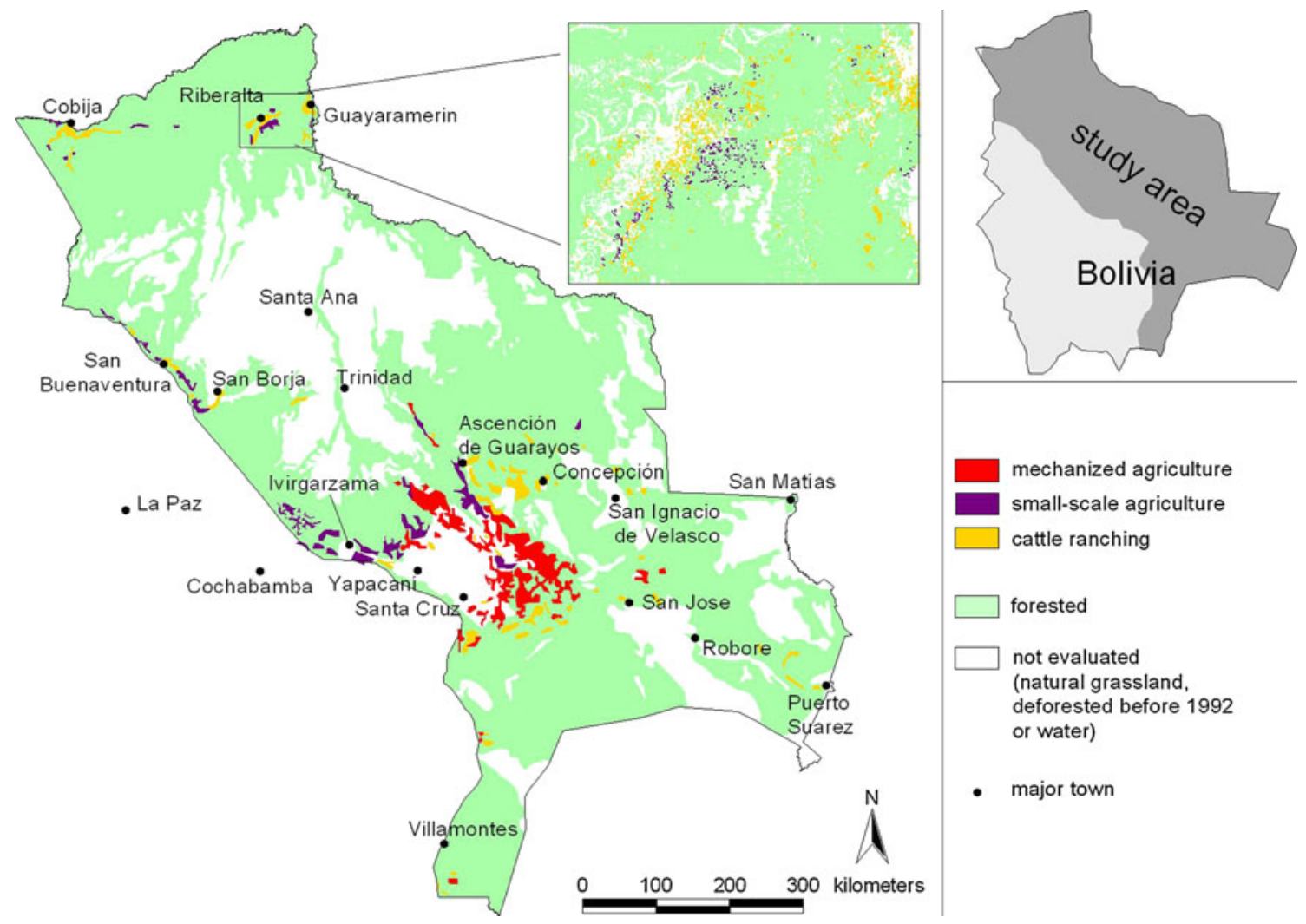

Fig. 3 Proximate causes of deforestation and forest persistence from 1992 to 2004. Source: Authors, based on sources indicated in Fig. 2. For this representation, raster data have been converted to polygons

Table 1 The contributions of the three proximate causes to deforestation between 1992 and 2004

\begin{tabular}{lcc}
\hline Land use & $\begin{array}{l}\text { Deforested area } \\
\left(\mathrm{km}^{2}\right)^{\mathrm{a}}\end{array}$ & $\begin{array}{l}\text { Percent of total } \\
\text { deforestation }\end{array}$ \\
\hline Agribusiness & 10,110 & 53.7 \\
Small-scale agriculture & 3,560 & 18.9 \\
Cattle ranching & 5,170 & 27.4 \\
Total deforested & 18,840 & 100.0 \\
\hline
\end{tabular}

Source: Authors

${ }^{\text {a }}$ Forest persistence 1992-2004: 399,060 km²

and consists of four unordered outcome categories: forest conversion due to mechanized agriculture, small-scale agriculture, and cattle ranching as well as stable forest. The four outcome categories were regressed against a set of independent variables that include geophysical, socioeconomic, and political factors. The coefficients are presented with stable forest as the base outcome or comparison category. For each of the three proximate causes, the resulting regression coefficients indicate the direction and strength of each independent variable's influence on forest conversion and allow us to rank the importance of each factor (Munroe and Müller 2007). The significance of coefficients manually; this facilitates visual interpretation but hides some smallscale patterns. See Supplemental Material for a map in higher resolution

is measured by $z$-statistics (Long and Freese 2006). We present the results as standardized logit coefficients and as odds ratios. Standardized logit coefficients can be used to compare the relative effects of the different independent variables and are calculated by multiplying the logit coefficient of an unstandardized independent variable by its standard deviation (Long and Freese 2006; Müller et al. 2011).

The spatial resolution of the regression analysis is $500 \mathrm{~m}$. We also tested a coarser resolution of $1 \mathrm{~km}$ to check for possible biases but did not encounter meaningful differences in the results. To correct for potential spatial autocorrelation in the dependent variable, we computed spatially lagged models that included cells from nonneighboring grids and estimated the regressions using samples from every second and every third grid cell in both the East-West and North-South directions (Besag 1974). Again, no substantial difference in the results was found between the two spatial samples. Correlation coefficients between independent variables never surpassed 0.8 which is mentioned as a critical threshold by Menard (2002). Only two pairs of variables showed correlations over 0.5, i.e., drought risk and fertile soils (0.74) as well as fertile soils and poor soils (0.52). Multinomial logit models can suffer 
Table 2 Descriptive statistics of independent variables

\begin{tabular}{|c|c|c|c|c|c|c|}
\hline Variable & Unit & Mean & SD & Minimum & Maximum & Year of information \\
\hline Excessive rainfall & $100 \mathrm{~mm}$ & 1.22 & 3.44 & 0 & 43 & \\
\hline Drought risk & $100 \mathrm{~mm}$ & 0.86 & 1.72 & 0 & 7 & \\
\hline Fertile soils & Binary & 0.15 & 0.36 & 0 & 1 & \\
\hline Poor soils & Binary & 0.61 & 0.49 & 0 & 1 & \\
\hline Slope & Degrees & 5.09 & 0.87 & 5 & 46 & \\
\hline Transportation costs to local markets & $\mathrm{US} \$ / \mathrm{t}$ & 35.89 & 22.11 & 0 & 118.1 & Road network of the mid-1990s \\
\hline Transportation costs to exportation markets (sea ports) & $\mathrm{US} \$ / \mathrm{t}$ & 118.05 & 32.37 & 30.2 & 203.8 & Road network of the mid-1990s \\
\hline National parks & Binary & 0.12 & 0.32 & 0 & 1 & Early 1990s \\
\hline Areas of integrated management & Binary & 0.07 & 0.25 & 0 & 1 & Early 1990s \\
\hline Forest concessions & Binary & 0.11 & 0.32 & 0 & 1 & 1997 \\
\hline Indigenous territories & Binary & 0.09 & 0.28 & 0 & 1 & Early 1990s \\
\hline
\end{tabular}

Number of observations: 1,668,104. Source: Authors

from a violation of the independence of irrelevant alternatives (IIA) that may occur if an additional land use outcome affects the relative probabilities of the other alternatives. Statistical tests for IIA such as the SmallHsiao and the Hausman test yield inconclusive results (Hilbe 2009; Long and Freese 2006). However, we argue that the choice of the three outcomes is unaffected by the potential presence of other outcomes and that they "can plausibly be assumed to be distinct and weighed independently in the eyes of each decision maker" (McFadden 1973, cited in Long and Freese 2006). Indeed, the inclusion of a hypothetical fifth land use option is unlikely to influence the weighting of the three proximate causes in the eyes of the local agents. The goodness of fit of calibration of the model was assessed by calculating the area under the curve (AUC) of the receiver operating characteristic (ROC; Pontius and Schneider 2001; Pontius and Pacheco 2004). The AUC was derived on the basis of continuous fitted probabilities that were calculated at varying cut-off values. An AUC of 0.5 indicates an accuracy equal to that of a random model, and a value of one indicates a perfect fit. Based on the coefficients obtained from the model, we also derived maps of the propensity of future deforestation by applying the modeled equations to the values of the independent variables for all cells in the study area.

\section{Independent variables}

The independent variables encompass geophysical factors, transportation costs, and land policies (Table 2). We selected these variables based on reviews of tropical deforestation studies (e.g., Geist and Lambin 2002; Kaimowitz and Angelsen 1998; Kirby et al. 2006; Mertens et al. 2004) and our field expertise in the study area. To reduce potential endogeneity biases, i.e., biases caused when the causality between dependent and independent variables may go both ways, we defined all variables according to their state at the beginning of the change period in 1992. When it was not possible to obtain exact data from 1992, we used the most suitable information available, e.g., the most recent map of forest concessions in 1997.

\section{Geophysical variables}

Rainfall The rainfall variables (Fig. 4) were based on a map of the mean annual precipitation presented in SoriaAuza et al. (2010). The map was generated using a modeling approach that combines long-term rainfall data from weather stations with topography. We transformed the rainfall data and created two variables to better capture climatic conditions that limit agricultural production (Müller et al. 2011). The variable excessive rainfall indicates the amount of annual rainfall that surpasses $1,700 \mathrm{~mm}$ in steps of $100 \mathrm{~mm}$, i.e., an area with $1,800 \mathrm{~mm}$ rainfall receives the value of one, an area with $2,000 \mathrm{~mm}$ of rainfall receives a value of three. Areas with precipitation below $1,700 \mathrm{~mm}$ receive a zero value. Drought risk is proxied by the amount of rainfall below $1,100 \mathrm{~mm}$ in steps of $100 \mathrm{~mm}$, i.e., an area with $800 \mathrm{~mm}$ rainfall receives a value of three. Areas with precipitation above $1,100 \mathrm{~mm}$ are labeled zero.

Soil fertility Soil fertility is represented by two dummy variables that were derived based on three generalized soil categories (Fig. 4). First, we defined the binary variable ferralitic soils and allocated a value of "one" to soils of the Precambrian Shield in the Chiquitania and the poor soils of the Amazonian north. In these areas, mainly Ferralsols, Plinthosols, and Acrisols (Gerold 2001, 2004) have been formed by ferralitization and clay lixiviation, resulting in low nutrient availability and low organic matter content. We delimited this zone based on the geological map of 


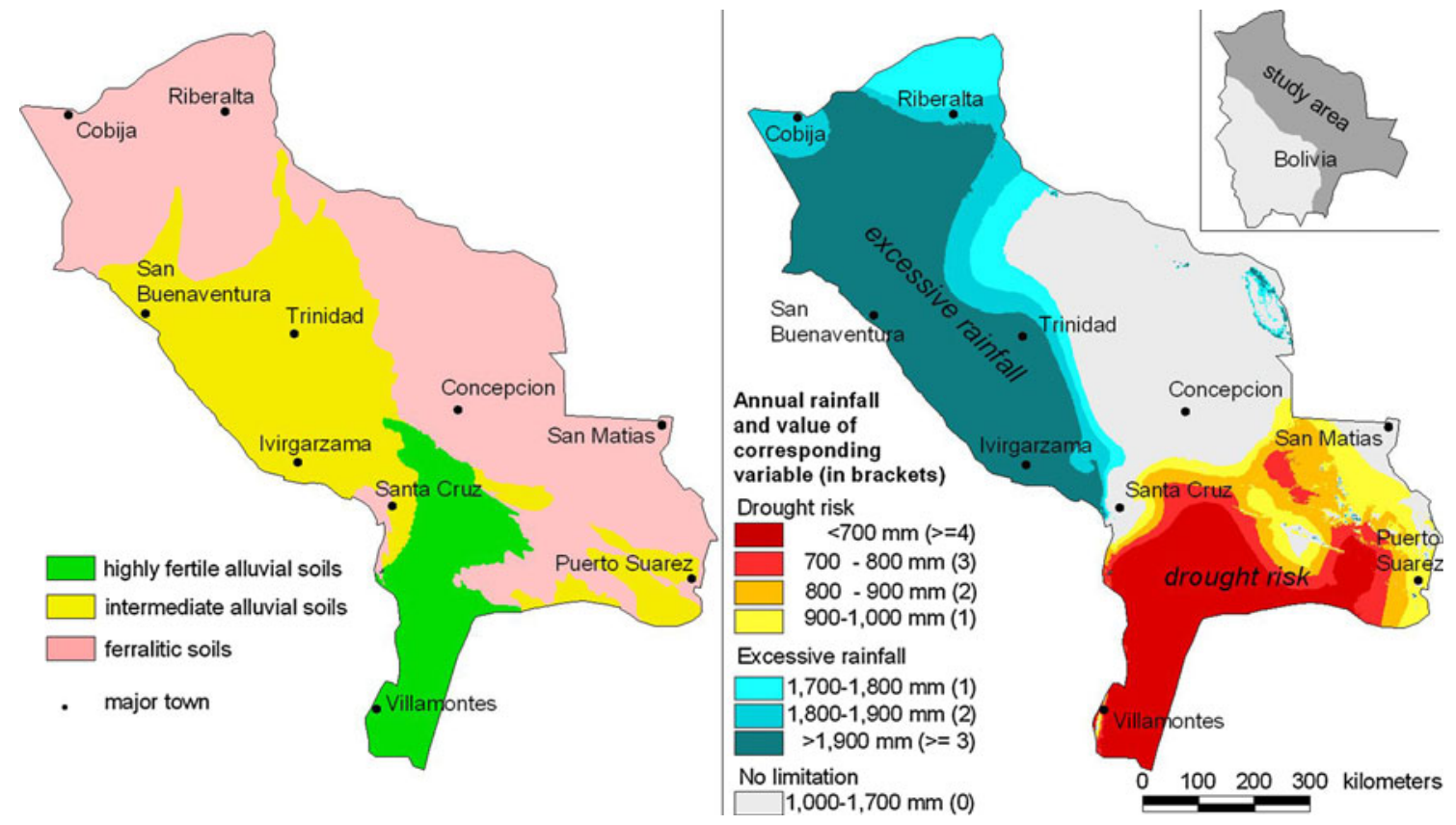

Fig. 4 Drought risk, excessive rainfall, and soil fertility. Source: Authors; rainfall data from Soria-Auza et al. (2010)

Bolivia (Servicio Geológico de Bolivia 1978) and the vegetation map of Navarro and Ferreira (2007). Second, we created the binary variable fertile soils where a value of "one" refers to a zone of alluvial soils from the area between the Rio Grande and the Brazilian Shield to the south of Bolivia, where Fluvisols with high nutrient availability and organic matter content are found (Gerold 2001). The limits of this zone were chosen based on expert knowledge (Gerold 2001, 2004; see Müller et al. 2011). Areas where both dummy variables are zero refer to alluvial soils with intermediate fertility that are influenced largely by white water streams; these areas were delimited based on the authors' judgment supported by the vegetation map of Navarro and Ferreira (2007).

Slope We used the Shuttle Radar Topography Mission (SRTM, USGS 2004) digital elevation model to calculate values of the slope variable in each grid cell in degrees. The elevation values of the SRTM model account for the height of vegetation. Therefore, the slope values at the forest edge appear overly high in flat areas because of the sharp distinction between low and high vegetation cover. To avoid this bias, we merged all slope values from 0 to $5^{\circ}$ into a single class (labeled " $5^{\circ}$ ") and grouped higher values in steps of $1^{\circ}$ ranging from $6^{\circ}$ to $46^{\circ}$ (see Müller et al. 2011).

\section{Access to markets}

We calculated transportation costs as a measure of physical access to markets (see Fig. 5). To avoid problems with road endogeneity (Müller and Zeller 2002), we included only major roads that connect major settlements (see Müller et al. 2011). To calculate transportation costs, we used a road network of the 1990s that differentiates between paved and dirt roads (Fig. 5, based on unpublished data obtained from the Bolivian road infrastructure authority Servicio Nacional de Caminos). Underlying transportation costs are applied in $\mathrm{US} \$ /(\mathrm{t} \mathrm{km})$ as 0.05 for paved roads, 0.1 for gravel and dirt roads, and 0.5 for land without roads (Müller et al. 2011). The road network serves to estimate the average transportation costs for transporting agricultural products from the farm gate to local and exportation markets. The variable transportation costs to local markets is defined by the transportation costs in US\$ per ton to the nearest settlement with more than 5,000 inhabitants. The variable transportation costs to export markets is defined by the transportation costs in US\$ per ton to the main ports for exportation of agricultural products, i.e., along the "Hydrovia" via the Paraguay River to the Atlantic and the road to the Pacific across the Bolivian highlands. To calculate the propensity of future deforestation, we modified the road network by changing the status of selected gravel and dirt roads into "paved roads" according to the observed road construction in the last years or road construction plans for the near future (Fig. 5). We also included the transportation costs via the bi-oceanic highway in the Amazonian north as an additional layer to capture future accessibility to export markets.

\section{Variables on land policies}

All variables related to land policies are shown in Fig. 5. The variable national parks includes all zoned areas that 


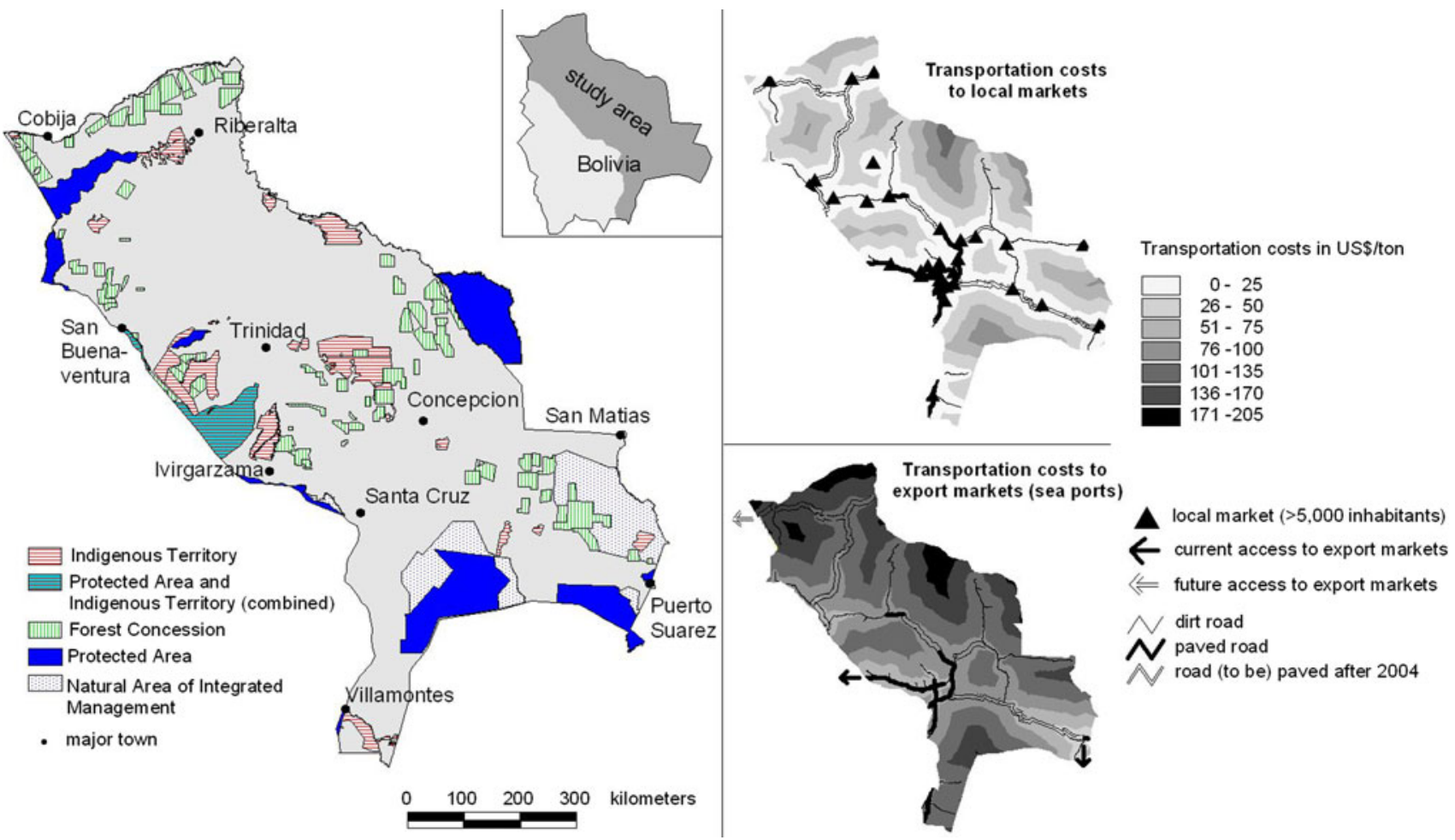

Fig. 5 Independent variables on market access and land policies. Sources: SERNAP, INRA and authors

are administrated by the national authority for protected areas (Servicio Nacional de Areas Protegidas, SERNAP,) and are attributed to the category of strict protection (national parks, reserves of flora and fauna and core zones of biosphere reserves). The variable areas of integrated management represents protected areas administrated by SERNAP but with a less strict protection status (Áreas Naturales de Manejo Integrado, ANMI). Data on both national parks and areas of integrated management were obtained directly from SERNAP and represent the state of the early 1990s. We define the variable forest concessions as the areas where private agents obtained the right to exploit timber for a 40-year period according to the rules of the Bolivian forestry law (No. 1700). The map of forest concessions was obtained from the former forestry state agency (Superintendencia Forestal) and characterizes forest concessions in 1997. The variable indigenous territories refers to the TCOs, which are rural communal properties granted to indigenous communities. These data characterize the situation in the early $1990 \mathrm{~s}$ and were obtained from the INRA.

\section{Potentially important variables that could not be included}

There are additional factors that potentially influence deforestation patterns in Bolivia, but suitable data are not available. Examples are flood risk, soil drainage, and land tenure (Müller et al. 2011). Land consolidation is still in process in Bolivia (INRA 2010). In populated and already deforested areas, it is generally more advanced than in sparsely populated and forested areas. Therefore the inclusion of inconsistent data on land tenure may bias the results, such data were thus excluded. We also refrained from using the variable "distance to prior deforestation", which often has high explanatory power in deforestation models (e.g., Kirby et al. 2006). However, besides its intrinsic meaning, this variable confounds other independent variables that triggered deforestation patterns in a former time step. Hence, issues with multicollinearity arise when including the distance to prior deforestation, and we therefore excluded this variable from the analysis (see Mertens et al. 2004; Müller et al. 2011).

\section{Propensity of future deforestation}

We derived maps of future deforestation propensity by applying the modeled equations to the independent variable's values for all forested cells in 2004 within the study area. For the variables representing access to markets, we used the updated road network (see "Access to markets"). Maps of deforestation propensity were used to allocate deforestation during 2004-2030, assuming that, for each of the three proximate causes of deforestation, the same quantity of square kilometers will be deforested per year as during the 1992-2004 period. In other words, the relative contribution of each proximate cause and the deforestation rate are assumed to remain constant (as in Table 1). Thus, 
the fitted probabilities derived from the regression are interpreted as purely relative measures of local propensity, whereas the quantity of expected forest conversion is derived by an independent procedure (see Pontius and Batchu 2003).

In the first step, the cells with the highest deforestation propensities were selected for each proximate cause until 2.17 times the number of cells deforested between 1992 and 2004 had been selected, because the 26 years from 2004 to 2030 correspond to 2.17 times the 12 years from 1992 to 2004. This procedure caused some cells to be selected for forest conversion more than once for different proximate causes. In such cases, we chose the category with the higher propensity of deforestation. For the unchosen category, additional cells were selected by reducing the corresponding propensity threshold. This procedure was repeated until the expected number of converted cells for each land use category was reached. The resulting map visualizes the future propensity for deforestation due to each proximate cause. This allocation strategy resembles the land use allocation procedure applied for example in the CLUE-S model (Verburg and Veldkamp 2004).

\section{Results}

Dynamics of land use change

The results of the MNL regressions characterize the dynamics of expansion of the three proximate causes of deforestation compared with stable forest (Table 3). For nine of eleven independent variables, the standardized coefficient is highest for mechanized agriculture, which indicates that this expansion pathway is best explained by the set of covariates. This is supported by the AUC, which is highest for the mechanized agriculture model (AUC $=0.97$, see also supplemental material). Mechanized agriculture mainly expanded in areas with good access to export markets and favorable environmental conditions. Fertile soil increased the likelihood of the expansion of mechanized agriculture by 15 -fold (odds ratio $=14.77$ ), whereas on poor soil, mechanized agriculture was approximately 50 times less probable to drive deforestation (odds ratio $=0.021$ ). A $100-\mathrm{mm}$ increase in annual rainfall in humid areas decreased the probability of the expansion of mechanized agriculture onto formerly forested areas by $50 \%$, and a $100-\mathrm{mm}$ reduction in rainfall had a comparable effect in drought-prone areas. A $1^{\circ}$ increase in slope reduced the probability of mechanized agriculture expansion by $32 \%$. The compliance of mechanized agriculture with land use restrictions appeared to be high, and little expansion was observed in protected areas, areas of integrated management, forest concessions, or indigenous territories. There was virtually no overlap between industrial agriculture and protected areas, which explains the extremely high value of the corresponding coefficient. This can also be interpreted as an indication that protected areas are mainly located in regions where the agricultural potential is low.

The expansion of small-scale agriculture was promoted predominantly by local market access, fertile soil, and humid climate conditions, and it was prevented by high drought risk. Compliance with land use restrictions was considerably lower for small-scale agriculture than for the

Table 3 Standardized logit coefficients and odds ratios (in brackets)

\begin{tabular}{lllrr}
\hline & Unit & Mechanized agriculture & Small-scale agriculture & Cattle ranching \\
\hline Excessive rainfall & $100 \mathrm{~mm}$ & $-2.56^{\mathrm{a}}(0.48)$ & $0.24(1.07)$ & $-0.06(0.98)$ \\
Drought risk & $100 \mathrm{~mm}$ & $-1.55(0.40)$ & $-2.82(0.19)$ & $-0.31(0.84)$ \\
Fertile soils & Dummy $(1 / 0)$ & $2.69(14.77)$ & $2.24(9.40)$ & $1.40(4.06)$ \\
Poor soils & Dummy $(1 / 0)$ & $-3.85(0.021)$ & $-1.91(0.15)$ & $0.40(1.48)$ \\
Slope & Degrees & $-0.34(0.68)$ & $-0.19(0.81)$ & $-0.15(0.85)$ \\
Transportation costs to local markets & US\$/t & $-0.35(0.98)$ & $-1.41(0.94)$ & $-1.83(0.92)$ \\
Transportation costs to exportation markets & US\$/t & $-0.99(0.97)$ & $-0.87(0.97)$ & $-0.14(1.00)$ \\
National parks & Dummy $(1 / 0)$ & $-51.21(0.00)$ & $-0.10(0.91)$ & $-1.17(0.31)$ \\
Areas of integrated management & Dummy $(1 / 0)$ & $-7.55(0.001)$ & $-1.61(0.20)$ & $-2.06(0.13)$ \\
Forest concessions & Dummy $(1 / 0)$ & $-1.63(0.20)$ & $-0.71(0.49)$ & $-0.78(0.46)$ \\
Indigenous territories & Dummy $(1 / 0)$ & $-7.09(0.001)$ & $-0.77(0.46)$ & $-0.87(0.42)$ \\
\hline
\end{tabular}

Source: Authors

a Standardized logit coefficients and odds ratios (in brackets) from the MNL model using stable forest as the base category. Coefficients of the dummy variables were not standardized. Observations without forest cover in 1992 were excluded. All coefficients are significant at the $99 \%$ level. $N=1,668,104$ 
other types of land use. Pixels inside a protected area were only $9 \%$ less likely to be converted to small-scale agriculture, and thus, parks were not very effective in halting this expansion pathway. Similarly, forest concessions and indigenous territories had marginal effects on this proximate cause of deforestation. The AUC was 0.96 (see also supplemental material) for small-scale agriculture, indicating an excellent calibrated fit of the model.

The expansion of cattle ranching was relatively less influenced by environmental conditions. The average of the absolute values of coefficients was much lower and the AUC was 0.84 (see also supplemental material). Although fertile soil increased the probability of cattle ranching by fourfold, poor soils also doubled its probability. This latter result is likely due to low competition with the other two proximate causes on poor soils. Access to local markets was an important driver of the expansion of cattle ranching, and an increase in transportation costs by one dollar per ton decreased the likelihood of cattle expansion by $8 \%$. In fact, cattle ranching expanded in most accessible locations across the study area. Compliance with land use restrictions was only slightly higher than in the case of small-scale agriculture.

\section{Propensity of future deforestation}

An evaluation of the propensity maps (Fig. 6) reveals that the expansion of mechanized agriculture is likely to be concentrated in areas where conditions are particularly suitable, mostly near the current areas of mechanized agriculture and particularly north of Ascención de Guarayos and near the Brazilian border (Puerto Suarez). The area near San Buenaventura in the northern Andean piedmont also shows some potential for expansion. Small-scale agriculture may experience the most expansion near the northern Andean piedmont but expansion is also predicted to some extent in areas identified as threatened by mechanized agriculture. The potential expansion of cattle ranching is more evenly distributed and threatens virtually all of the accessible forest areas in the lowlands, but there is particularly a high propensity of expansion in the Amazonian north, the Chiquitania, and the southern Andean foothills near Villamontes. This is consistent with the observation that the expansion of cattle ranching is relatively indifferent to environmental conditions. The map of projected deforestation clearly identifies areas around Cobija, Riberalta, Concepción, San Ignacio de Velasco, San José de Chiquitos and Villamontes as the most threatened by conversion to cattle ranching.

In the lower right of Fig. 6, these findings are combined to depict the projected land use in 2030 . The resulting map predicts an expansion of each of the three proximate causes near areas where the same land uses are currently practiced (compare with Fig. 3), i.e., mechanized agriculture near Santa Cruz, small-scale agriculture at the northern Andean piedmont, and cattle ranching near local market centers in the Chiquitania and Amazonian north. In addition, an expansion of mechanized agriculture into new areas near Puerto Suarez and San Buenaventura is likely. We do not show a map of propensity for the category stable forest because we are mainly interested in the propensities of conversion.

\section{Discussion and substantiation of the regression results}

The multinomial logit model allowed us to evaluate spatial determinants of deforestation between 1992 and 2004. These findings are useful as they permit valuable insights into the land use transitions in the recent past (Table 3) and facilitate awareness of potential future pathways (Fig. 6). We first discuss the plausibility of the model's results and then connect these results with the context of historical land use changes in lowland Bolivia to analyze potential drivers and legacies that cannot be captured by the model. It is not surprising that the predicted expansion of each type of land use is concentrated near areas already under the same land use. This suggests an increasing spatial concentration of land use dynamics in the study area and indicates that land use determinants are spatially clustered. The result is noteworthy, however, because the distance to prior deforestation was not included as a covariate in the model. In the case of mechanized agriculture, the model predicts new potential hotspots of forest conversion near Puerto Suarez and near San Buenaventura (Fig. 6). In the area surrounding Puerto Suarez, fertile alluvial soils and beneficial access to export markets via the Paraguay River foster the expansion of mechanized agriculture. In addition, experimental soybean plantations have been initiated in this area by international corporations (CIAT Santa Cruz, Centro de Investigación Agrícola Tropical, personal communication). In the area surrounding San Buenaventura, an agro-industrial complex for the production and processing of sugarcane has long been planned, and these plans have been revived under the current government (Malky and Ledezma 2010). Soils are of intermediate quality, but access to $\mathrm{La} \mathrm{Paz}$ is fairly good. Thus, the predicted expansion of mechanized agriculture into these two new hotspots indeed captures probable future dynamics. The predicted land use in 2030 is based not only on the regression results, which reveal spatial patterns, but also on the assumption that deforestation will continue at the same rate observed in the past. This is one of many possible scenarios because an alteration of macroeconomic or political drivers can considerably alter the demand for agricultural products. For example, a future expansion of 


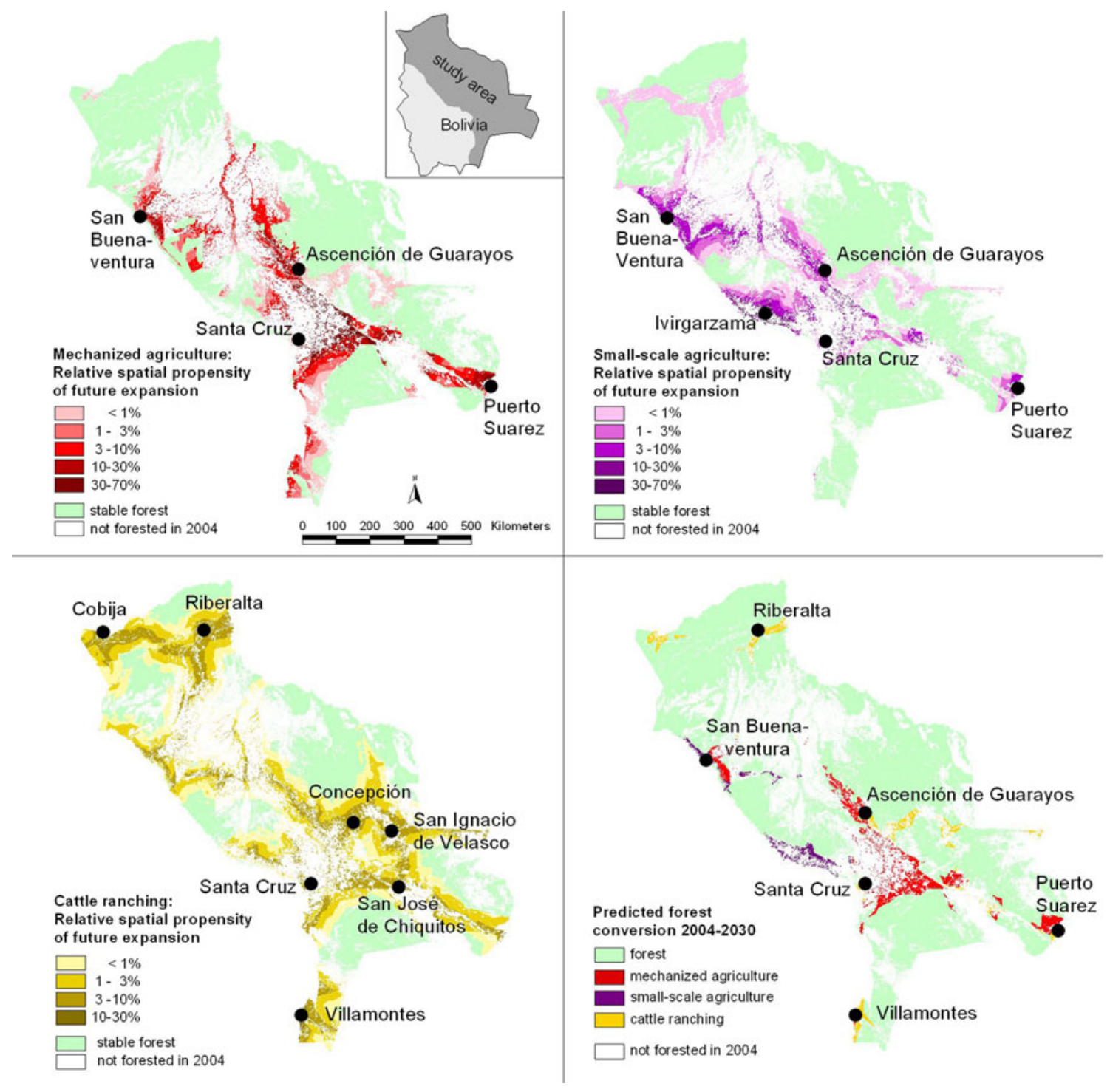

Fig. 6 Propensities of agricultural expansion from 2004 to 2030. Source: Authors

mechanized agriculture will depend on macroeconomic conditions, such as those linked to prices of agricultural commodities, exchange rates, or the success of Bolivia in securing markets for exportation (see Morton et al. 2006; Nepstad et al. 2006; Pacheco 2006a).

As follows, we intend to enrich the discussion of the regression results by analyzing spatial dynamics of land use change in a historical context to identify additional drivers and land use legacies for the different zones of the study area that may shape historical and future land use patterns (see Liu et al. 2007). The development of the Amazonian north was originally triggered by the rubber boom some 150-100 years ago. Cattle ranching was first adopted as a supplementary land use activity that provided animal products to the rubber tappers that settled in the rubber land estates (Gamarra Téllez 2004). However, over time, cattle ranching has taken over the more accessible forest areas that were first opened by the logging industry and later converted to pastures. As a consequence, access to local markets seems to be the most valid spatial determinant shaping the spatial patterns of cattle ranching in this area to date. This is plausible and validates the finding of the regression model that indicates relative indifference toward environmental conditions. In addition, the inability of other agricultural activities to prosper in the Amazonian north, probably also due to the economic dominance of Brazil nut extraction, is in line with the model's finding that cattle ranching is currently the only viable farming activity on the poor ferralitic soils of the Amazonian north. Land use patterns in the northern 
Andean piedmont were originally shaped by governmentplanned settlements of poor rural internal migrants ("colonos") who originated from western Bolivia and practiced small-scale agriculture. An important factor for the successful establishment of smallholders in this area may have been the persistence of linkages between these settlers and their areas of origin because many "colonos" tend to maintain strong connections to their places of origin in the dry valleys and highlands, which are relatively near to the northern Andean piedmont. The regression model therefore tends to overestimate the importance of climatic conditions as a determinant of small-scale agriculture because it does not capture the persistence of cultural associations. In turn, settlers of foreign origin, mainly the Mennonites and Japanese, are important agents in mechanized agriculture in the surroundings of Santa Cruz. Government policies between the 1950s and the 1970s assigned land to these settlers, along with national producers, in areas near Santa Cruz with the objective of enhancing the production of sugarcane and cotton for the national market as part of a broader plan aimed at import substitution of these agricultural goods for the domestic market (Pacheco 2006a). These programs strongly shaped patterns of mechanized agriculture but-since the high agricultural potential of the area was known - they also promoted land occupation within the spatial potential identified by the multinomial logit model. The same is valid for the program to support agricultural development by multilateral donors during the early 1990s in the expansion zone in eastern Santa Cruz (Baudoin et al. 1995; Hecht 2005; Gerold 2007). In the Chiquitania, where cattle ranching is the predominant economic activity, land use patterns were originally shaped by the locations of Jesuit missions (Tonelli Justiniano 2004). As in the Amazonian north, the prevalence of cattle ranching is likely due to the poor quality of soils, which limits other agricultural activities. This is also in line with the regression results.

The discussion reveals that the regression model and the maps of propensity of future deforestation deliver plausible results but merely reflect a portion of the dynamics determining land use change. An inspection of historical land use reveals underlying drivers and historical legacies that cannot be emulated by regression analysis. However, such legacies not only affect historical trajectories but can also have a bearing on future developments and therefore can cause large deviations from predicted land use changes. For instance, it is possible that the strong political support by the current government for smallholders originating from western Bolivia and the government's interest in securing political influence in the Amazonian north might lead to a stronger expansion of small-scale agriculture in this zone than that projected by our model.

\section{Conclusions}

We have explored the spatial dynamics of the expansion of the three main proximate causes of deforestation in the Bolivian lowlands. Mechanized agriculture caused the largest share of deforestation, followed by cattle ranching and small-scale agriculture. For the period between 1992 and 2004, we estimated a spatially explicit multinomial logistic regression using these three proximate causes of deforestation as outcome categories. The set of predictor variables captures the natural suitability of a location, physical accessibility conditions, and land policies that can all be assumed to shape the expansion of agriculture into previously forested areas. The regression results were used to predict the likely future of deforestation throughout the Bolivian lowlands. To corroborate the regression results, we also conducted a qualitative analysis of historical drivers and legacies of land use that have shaped long-term land use patterns in the Bolivian lowlands to date. Placing the regression into a broader historical context augmented the discussion of regression outcomes and facilitated a more profound assessment of the future deforestation risks.

The model suggests that the expansion of mechanized agriculture will occur in areas with good access to international markets and favorable environmental conditions, whereas land use restrictions efficiently prevent the expansion of mechanized agriculture. Potential future deforestation due to mechanized agriculture will likely occur to the North and the South of its current extension, but newly emerging frontier areas near Puerto Suarez and San Buenaventura may also open up. The expansion of small-scale agriculture is predicted to be concentrated in areas with a humid climate, good soil, and local market access. The compliance with land use restrictions is low in this category, and designation of protected areas has little effect on curbing deforestation arising from small-scale agriculture. In the future, small-scale agriculture will likely continue to expand in humid areas at the northern Andean piedmont. Forest conversion for cattle ranching is largely independent of environmental factors and is instead driven by access to local markets. Land use restrictions are also relatively ineffective in delaying the expansion of cattle ranching. The future of cattle ranching is likely to affect various parts of the Bolivian lowlands without dominant spatial clusters.

Our results can aid in the development of policies aimed to reduce deforestation, e.g., in the context of REDD. An important part of such policies may be a national land use plan that admits expansion into some suitable areas while restricting expansion in other areas. This may avoid the development of new deforestation hotspots, for example, due to the expansion of mechanized agriculture. The regulation of small-scale agriculture, which has caused much 
less deforestation in the past, may be even more demanding because compliance to land use restrictions is low and monitoring costs are likely to be high because of the large number of agents. The mitigation of deforestation caused by small-scale agriculture may be important in the Amazonian north, where small-scale farming will probably expand despite the low natural suitability. For a reduction of the expansion of cattle ranching, which threatens forests in many different parts of the Bolivian lowlands, the enforcement of land use legislation seems most adequate and might avoid large illegal clearings (Superintendencia Forestal 2006).

The presented regression analysis helps distinguish the specific dynamics of forest conversion due to different proximate causes. Moreover, the model allows calculations of the propensity of agricultural expansion, which in turn facilitates the prediction of future deforestation. However, the interpretation of regression models can lead to erroneous conclusions due to a dearth of knowledge of the historical framework. In particular, the timing and quantity of forest conversion are often affected by political interventions and historical legacies that are difficult to capture in regression models. A strength of these models is their ability to elucidate the spatial patterns of recent changes and statistically infer their determinants. However, supplementing the models with explanatory frameworks based on long-term historic drivers and legacies can render the inferences more convincing and generate more valuable insights for policy and management.

Acknowledgments We are grateful to the Noel Kempff Mercado Museum of Natural History in Santa Cruz and Conservation International Bolivia for sharing the extensive data set on deforestation. Several Bolivian institutions and individuals have helped with data and provided support during the field work, in particular, Centro de Investigación y Promoción del Campesinado (CIPCA), Fundación Amigos de la Naturaleza (FAN), Fundación NATURA Bolivia, and Fundación para la Conservación del Bosque Seco Chiquitano. Peter Böhner provided a map of average annual rainfall. Two anonymous reviewers helped to improve the manuscript with many valuable comments. We also thank the Deutsche Forschungsgemeinschaft (DFG) for funding.

Open Access This article is distributed under the terms of the Creative Commons Attribution Noncommercial License which permits any noncommercial use, distribution, and reproduction in any medium, provided the original author(s) and source are credited.

\section{References}

Baudoin M, Gerold G, Hecht S, Quintanilla O, Roca C (1995) Evaluación del Proyecto Tierras Bajas del Este: Proyecto de Manejo de Recursos Naturales y de Producción Agropecuaria. World Bank; Kreditanstalt fur Wiederaufbau, CORDECRUZ. World Bank, Washington, DC
Besag JE (1974) Spatial interaction and the statistical analysis of lattice systems. J R Stat Soc B 36:192-236

CADEX (Cámara de Exportadores de Santa Cruz) (2008) Statistical information on Bolivia exports, available on request. CADEX, Santa Cruz, Bolivia

CAO (Cámara Agropecuaria del Oriente) (2008) Números de nuestra tierra. Statistical agricultural information available on CD-ROM at the Cámara Agropecuaria del Oriente, Santa Cruz, Bolivia

Chomitz K, Gray D (1996) Roads, land use and deforestation: a spatial model applied to Belize. Word Bank Econ Rev 10(3):487-512

Eastwood D, Pollard H (1985) The development of colonization in lowland Bolivia: objectives and evaluation. Boletín de Estudios Latinoamericanos y del Caribe 38:61-83

FAO (Food and Agriculture Organization of the United Nations) (2010) Global forest resources assessment 2010. Food and Agriculture Organization of the United Nations, Rome. http://www.fao.org/forestry/fra/fra2010/en/. Accessed Nov 2009

Gamarra Téllez M (2004) Amazonía Norte de Bolivia-Economía Gomera. Colección Colegio Nacional de Historiadores de Bolivia, producciones CIMA editores. La Paz, Bolivia

Geist HJ, Lambin EF (2002) Proximate causes and underlying driving forces of tropical deforestation. Bioscience 52:143-150

Gerold G (2001) The pedo-ecological consequences of different land use-systems in the Lowlands of Bolivia (Dep. of Santa Cruz). In: García-Torres L, Benites J, Martinez-Vilela A (eds) Conservation agriculture, a worldwide challenge, vol 2. ECAF, Madrid, pp 275-279

Gerold G (2004) Soil: the foundation of biodiversity. In: Ibisch PL, Mérida G (eds) Biodiversity: the richness of Bolivia. Fundación Amigos de la Naturalzea, Santa Cruz, Bolivia, pp 17-31

Gerold G (2007) Agrarkolonisation-Entwicklungschancen durch Globalisierung oder Raubbau natürlicher Ressourcen. Kieler Geographische Schriften 117:23-52

Hecht S (2005) Soybeans, development and conservation on the Amazon frontier. Dev Change 36(2):375-404

Hilbe JM (2009) Logistic regression models. Chapman \& Hall/CRC, Boca Raton

Hosmer D, Lemeshow S (2000) Applied logistic regression, 2nd edn. Wiley, New York

Ibisch PL, Beck SG, Gerkmann B, Carretero A (2003) Ecorregiones y ecosistemas. In: Ibisch PL, Mérida L (eds) Biodiversidad: la riqueza de Bolivia. Editorial FAN, Santa Cruz de la Sierra, Bolivia, pp 47-88

INPE (Instituto Nacional de Pesquisas Espaciais) (2010) Collection of CBERS satellite images. http://www.inpe.br/index.php. Accessed Dec 2010

INRA (Instituto Nacional de Reforma Agraria) (2010) Notas de Prensa. http://www.inra.gob.bo. Accessed Feb 2011

IPCC, 2007: Climate Change 2007: The Physical Science Basis. Contribution of Working Group I to the Fourth Assessment Report of the Intergovernmental Panel on Climate Change, S. Solomon, D. Qin, M. Manning, Z. Chen, M. Marquis, K.B. Averyt, M. Tignor and H.L. Miller, Eds., Cambridge University Press, Cambridge, UK and New York, NY, USA, 996pp.

Kaimowitz D, Angelsen A (1998) Economic models of tropical deforestation: a review. Center for International Forestry Research. Bogor, Indonesia

Killeen TJ, Calderon V, Soria L, Quezada B, Steininger MK, Harper G, Solórzano L, Tucker C (2007) Thirty years of land-cover change in Bolivia. Ambio 36(7):600-606

Killeen TJ, Guerra A, Calzada M, Correa L, Calderon V, Soria L, Quezada B, Steininger MK (2008) Total historical land-use change in Eastern Bolivia: who, where, when, and how much? Ecol Soc 13(1):36. http://www.ecologyandsociety.org/vol13/ iss $1 /$ art36/. Accessed June 2009 
Kirby KR, Laurance WF, Albernaz AK, Schroth G, Fearnside PM, Bergen S, Venticinque EM, da Costa C (2006) The future of deforestation in the Brazilian Amazon. Futures 38(4):432-453

Liu J, Dietz T, Carpenter SR, Alberti M, Folke C, Moran E, Pell AN, Deadman P, Kratz T, Lubchenco J, Ostrom E, Ouyang Z, Provencher W, Redman CL, Schneider SH, Taylor WW (2007) Complexity of coupled human and natural systems. Science 317:1513-1516

Long JS, Freese J (2006) Regression models for categorical dependent variables using stata. Stata Press, College Station

Malky A, Ledezma J (2010) Factibilidad económica y financiera de la producción de caña de azúcar y derivados en el norte del departamento de La Paz. Conservation Strategy Fund, Serie Técnica 18, La Paz, Bolivia

Menard S (2002) Applied logistic regression analysis, 2nd edn. Sage, Thousand Oaks

Merry FD, Hildebrand PE, Pattie P, Carter DR (2002) An analysis of land conversion from sustainable forestry to pasture. A case study in the Bolivian Lowlands. Land Use Policy 19(3):207-219

Mertens B, Kaimowitz D, Puntodewo A, Vanclay J, Mendez P (2004) Modeling deforestation at distinct geographic scales and time periods in Santa Cruz, Bolivia. Int Reg Sci Rev 27(3):271-296

Miles L, Kapos V (2008) Reducing greenhouse gas emissions from deforestation and forest degradation: global land-use implications. Science 320:1454-1455

Montes de Oca I (2004) Enciclopedia Geográfica de Bolivia. Editora Atenea. La Paz, Bolivia

Morton DC, DeFries RS, Shimabukuro YE, Anderson LO, Arai E, del Bon Espirito-Santo F, Freitas R, Morisette J (2006) Cropland expansion changes deforestation dynamics in the southern Brazilian Amazon. Proc Natl Acad Sci 103(39):14637-14641

Müller D, Zeller M (2002) Land-use dynamics in the central highlands of Vietnam: a spatial model combining village survey data with satellite imagery interpretation. Agric Econ 27(3):333-354

Müller R, Müller D, Schierhorn F, Gerold G (2011) Spatiotemporal modeling of the expansion of mechanized agriculture in the Bolivian lowland forests. Appl Geogr 31(2):631-640

Munroe DK, Müller D (2007) Issues in spatially explicit statistical land-use/cover change (LUCC) models: examples from western Honduras and the Central Highlands of Vietnam. Land Use Policy 24:521-530

Munroe DK, Southworth J, Tucker CM (2004) Modeling spatially and temporally complex land cover change: the case of Western Honduras. Prof Geogr 56(4):544-559

Museo Noel Kempff and Prefectura de Santa Cruz (2008) Cobertura y Uso Actual de la Tierra. Land use map of the Santa Cruz department. Santa Cruz, Bolivia. http://www.museonoelkempff. org/sitio/descargar_archivo.php?id=3134. Accessed June 2011

Navarro G, Ferreira W (2007) Mapa de Vegetación de Bolivia a escala 1:250,000. On CD-ROM. The Nature Conservancy (TNC), RUMBOL. Cochabamba, Bolivia

Navarro G, Maldonado M (2002) Geografía ecológica de Bolivia. Vegetación y ambientes acuáticos. Fundación Simón I. Patiño. Cochabamba, Bolivia

Nepstad DC, Stickler CM, Almeida OT (2006) Globalization of the Amazon soy and beef industries: opportunities for conservation. Conserv Biol 20:1595-1603
Pacheco P (1998) Estilos de desarrollo, deforestación y degradación de los bosques en las tierras bajas de Bolivia. CIFOR, CEDLA, TIERRA. La Paz, Bolivia

Pacheco P (2006a) Agricultural expansion and deforestation in lowland Bolivia: the import substitution versus the structural adjustment model. Land Use Policy 23:205-225

Pacheco P (2006b) Acceso y uso de la tierra y bosques en Bolivia: sus implicaciones para el desarrollo y la conservación. UDAPE, La $\mathrm{Paz}$

Pacheco P, Ormachea E, Cronkleton P, Albornoz MA, Paye L (2009) Trayectorias y tendencias de la economía forestal extractiva en el norte amazónico de Bolivia. CIFOR, CEDLA, RRI. La Paz, Bolivia

Pontius RG, Batchu K (2003) Using the relative operating characteristic to quantify certainty in prediction of location of land cover change in India. Trans GIS 7(4):467-484

Pontius RG, Millones M (2011) Death to Kappa: birth of quantity disagreement and allocation disagreement for accuracy assessment. Int J Remote Sens 32(15):4407-4429

Pontius RG, Pacheco P (2004) Calibration and validation of a model of forest disturbance in the Western Ghats, India 1920-1990. GeoJournal 61(4):325-334

Pontius RG, Schneider L (2001) Land-cover change model validation by an ROC method for the Ipswich watershed, Massachusetts, USA. Agric Ecosyst Environ 85:239-248

Sandoval CD, Sandoval AV, del Río MA, Sandoval F, Mertens C, Parada C (2003) Santa Cruz-Economía y poder. Fundación PIEB. La Paz, Bolivia

Servicio Geológico de Bolivia (1978) Mapa Geológico de Bolivia, 1:1,000000. Servicio Geológico de Bolivia. La Paz, Bolivia

Soria-Auza RW, Kessler M, Bach K, Barajas-Barbosa PM, Lehnert M, Herzog S, Böhner J (2010) Impact of the quality of climate models for modelling species occurrences in countries with poor climatic documentation: a case study from Bolivia. Ecol Model 221:1221-1229

Stoian D, Henkemans AB (2000) Between extractivism and peasant agriculture: differentiation of rural settlements in the Bolivian Amazon. Int Tree Crops J 10(4):299-319

Superintendencia Forestal (2006) Avance de la deforestación en Bolivia. Tasa anual de deforestación en los años 2004 y 2005. Superintendencia Forestal, Santa Cruz de la Sierra, Bolivia

Thiele G (1995) La dinámica del asentamiento campesino en la frontera agrícola en Santa Cruz. Revista Ruralter 13/14:109-146

Tonelli Justiniano O (2004) Reseña histórica social y económica de la Chiquitania. Editorial El País. Santa Cruz, Bolivia

USGS (U.S. Geological Survey) (2004) 3 Arc second SRTM elevation model, unfilled unfinished 2.0. Global Land Cover Facility, University of Maryland, Maryland. http://www.land cover.org/data/srtm/. Accessed Nov 2009

Verburg PH, Veldkamp A (2004) Projecting land use transitions at forest fringes in the Philippines at two spatial scales. Landscape Ecol 19(1):77-98

Verburg PH, Kok K, Pontius RG, Veldkamp A (2006) Modeling landuse and landcover change. In: Lambin EF, Geist HJ (eds) Landuse and land-cover change: local processes and global impacts. Springer, Berlin, pp 117-135 